\title{
trabalhonecessário
}

issn: 1808-799X

ano 9 - número $12-2011$

\author{
ENSAIO
}

\section{EDUCAÇÃO E NÃO EMANCIPAÇÃO. Os limites da educação escolar na organização social contemporânea}

\author{
Cesar Augusto Alves da Silva ${ }^{1}$
}

Não há lugar numa fábrica para um sábio

Fritz Ringer

\section{Resumo}

O presente escrito tem como objetivo analisar a possível obsolescência da educação escolar para o desenvolvimento e a inserção dos indivíduos no ora vigente modo de produção capitalista industrial. Esta análise se baseia na descrição de Marx dos momentos constitutivos do capital através do modo de produção de mercadorias. Nesta exposição ele demonstra a existência de uma lógica interna própria para a dinâmica da construção do capital em seu movimento eterno de expansão. Mais do que isso, há a erupção de relações sociais a partir desse processo de produção e expansão do capital, mediado pela mercadoria, sem que haja a necessidade interna ou externa de um sistema de ensino massivo de indivíduos para que isso se realize. Pelo contrário, se a produção capitalista necessita de um consumo sempre em expansão de seus produtos, a indústria cultural se encarrega de realizá-lo. Em suma, procuramos demonstrar a partir dos escritos, principalmente, de Marx, Adorno e Marcuse que a demanda do modo de produção capitalista por uma massa de indivíduos oriundos da educação escolar não existe, pois a maioria de suas demandas radica nele mesmo, modo de produção, e são solucionadas por ele mesmo em seu processo de constituição, não num elemento externo e ideal, como é o caso da educação escolar. Desta forma, não há como sustentar argumentos que impingem a educação escolar como um elemento fundamental na criação ou no acesso a empregos e muito menos numa prerrogativa para a expansão da assim chamada economia atual, isto é, as relações de produção capitalistas que são constitutivas deste modo de produção. A partir daí,

\footnotetext{
${ }^{1}$ Mestre em Educação:Currículo pela PUC de São Paulo; professor de História da rede pública do Estado de São Paulo.
} 


\section{trabalhonecessário}

issn: 1808-799X

ano 9 - número 12 - 2011

podemos perceber a brecha que se abre para a educação escolar no que tange à formação (no sentido privilegiado da Bildung) dos seres humanos. Porém, tal formação é absolutamente obstruída pelo âmbito objetivo da reificação, isto é, a produção da semiformação. Concluímos reiterando a necessidade da abordagem do tema educacional a partir da totalidade do processo de produção social da vida sob um enfoque marxista.

\section{Palavras chave: Educação, capitalismo, semiformação}

\section{Abstract}

This writing is intended to analyze the necessity of schooling for the development and inclusion of individuals in the prevailing industrial capitalist mode of production. This analysis is based on Marx's description of the constitutive moments of capital by way of production of goods. In this exhibition he shows the existence of an own internal logic for the dynamic construction of capital in its eternal movement of expansion. More than that, there is the eruption of social relations from this process of production and capital expansion, mediated by commodity, without the need for internal or external to a mass education system of individuals for which this takes place. Rather, the capitalist production requires an ever-expanding consumption of its products, the culture industry is responsible for realizing it. In short, we seek to demonstrate, from the writings of Marx and Adorno, that the demand of capitalist mode of production by a mass of individuals from school education does not exist because most of their demands lies in himself, mode of production, and are solved by himself in the process of creation, not a foreign element and ideal, as is the case of school education. Thus, we can not support arguments that impinge on the school education as a fundamental element in the creation or access to jobs. Much less a prerogative for the expansion of socalled current economy, that is, the capitalist production relations that are constitutive of that method. From there, we can see the gap that opens for school education in relation to training (in the sense of privileged Bildung) in humans. However, such training is completely blocked by the objective context of reification, the production of erudition. We conclude by reiterating the need to approach the topic of education from the entire production process of social life under

marxist.

Keywords: education, capitalism, erudition

Educação e produção material: limites objetivos à produção autônoma de idéias. 


\section{trabalhonecessário}

issn: $1808-799 \mathrm{X}$

ano 9 - número 12 - 2011

Na organização social brasileira contemporânea, a educação tem sido colocada como sendo de fundamental importância para o desenvolvimento dos indivíduos e do país. No momento atual existem, neste país, inúmeras entidades governamentais, privadas e não governamentais mergulhadas em campanhas por um aumento ainda maior na massificação da educação. Tanto órgãos públicos quanto privados têm repetido à exaustão o bordão de "todos pela educação". Os governos têm investido milhões de dólares neste setor público. Tal verba vem se traduzindo em novas tecnologias, equipamentos eletrônicos de multimídia, bibliotecas, livros (didáticos e não didáticos), melhorias de prédios e construção de outros, material escolar, campanhas publicitárias, etc.. As operações governamentais para estimular os indivíduos a freqüentarem a escola se multiplicam, indo desde estímulos em dinheiro aos pais daqueles assíduos participantes do cenário escolar até alimentos. Grandes conglomerados midiáticos produzem canais educativos e campanhas de solidariedade fraternal para ajudar escolas públicas, colocando em ação até seus astros e estrelas. As ONGs (organizações não governamentais) entram também neste negócio da educação como salvação para o indivíduo e para o país. Uma simples pesquisa pela internet pode revelar uma infindável lista de institutos, entidades e organizações - todos sob a sigla "não governamental" dedicadas a levar a educação àqueles distantes dela em razão da miséria e da pobreza causada, segundo os adeptos do "discurso" educativo, pela própria falta de educação. Há uma entonação em uníssono clamando aos deuses escolares para receber suas bênçãos divinas. A "skolá", isto é, o ócio, vive seus dias de glória em meio à sociedade do trabalho ${ }^{2}$. A centralidade do trabalho permanece e adiciona o ócio em seu movimento de reprodução: "Investimento em Educação ampliado e bem gerido" prescreve a última meta do documento intitulado "5 metas que o Brasil precisa alcançar até 2022"

\footnotetext{
${ }^{2}$ A rigor, tal organização social nos parece ser alimentada por uma forma social já ultrapassada pelo desenvolvimento das forças produtivas, mas que insiste em existir obnubilando as relações de produção e as colocando em frontal contradição com aquelas forças, porém, não concedendo espaço à revolução como o conhecido prognóstico de Marx.
} 


\section{trabalhonecessário}

issn: 1808-799X

ano 9 - número 12 - 2011

publicado no site www.todospelaeducação.org.br, um movimento composto por diversos setores da sociedade e que conta com o patrocínio de grandes conglomerados bancários, industriais e da construção civil. Porém, se dizem um "projeto de Nação" e "não o projeto de uma organização específica".

As vozes podem ser ouvidas em todos os cantos do país, clamando favoravelmente à educação como salvação das almas errantes. Desde uma parte daqueles que estão acoplados ao espectro de pensamentos que percebem na estrutura produtiva a raiz dos males que afligem os campos econômico, social e cultural, até os que, escandalosamente, defendem a citada estrutura (isto é, o capital), acreditam e receitam a educação como remédio para tais males. Para os primeiros a educação é capaz de iluminar as mentes de cada um dos indivíduos e lançá-los à revolução após tal iluminação, pois traria a consciência até eles de que há terríveis contradições imanentes ao próprio sistema capitalista, cuja existência oprime os seres humanos e não thes permite nem mesmo vislumbrar o que seria a autonomia. Discussões acerca da educação como caminho redentor, capaz de proporcionar a autonomia ou a emancipação, sem levar em consideração a configuração social a partir dos limites objetivos colocados pela produção e reprodução do capital e que, nesse processo - considerado em sua totalidade, isto é, produção e consumo efetivamente "concedem" formação àqueles que dele fazem parte, preenchem a vida cotidiana de alguns pensadores.

Já para aqueles que acreditam no poder civilizatório do capital, a educação se torna um instrumento com poderes mágicos capazes de solucionar a miséria material em que sobrevivem os moradores dos bairros miseráveis. Numa ação ideológica ainda maior, eles municiam as armas contra a violência, urbana ou rural, com lápis, cadernos, livros, lousas e giz. É comum - "discurso" que se pronuncia contra a violência crônica que assola as pequenas e grandes cidades indicar a falta de educação escolar como provável causa desta última e, portanto, seu suprimento enquanto solução. A escassez de postos de trabalho é outro problema - objetivo, estrutural e imanente ao 


\section{trabalhonecessário}

issn: $1808-799 \mathrm{X}$

ano 9 - número 12 - 2011

próprio sistema capitalista industrial - que a educação, segundo aqueles que acreditam nela como remédio para todos os males, é capaz de resolver. Não obstante, a organização do mundo social contemporâneo é fundamentada numa forma específica, isto é, historicamente determinada, de produzir e reproduzir materialmente a vida humana e o próprio mundo que, desde seu início, independeu do nível de escolarização da massa de seus produtores e consumidores. Com efeito, tal organização apresenta uma dinâmica interna apresentada por Marx principalmente em "O Capital" - que em nenhum momento alude à educação como elemento constitutivo dela. Pelo contrário, a organização capitalista da produção material define, por si mesma, em seu processo de produção e reprodução do mundo, e retroativo das necessidades, algo imaterial, isto é, a (semi)formação dos indivíduos que a integram (Cf. Adorno, 1986, pp. 388-411).

Ora, se reconhecermos que as necessidades primeiras do ser humano são fisiológicas e unicamente satisfeitas por produtos materiais, então concluiremos que, sendo primeiras, devem ser satisfeitas em primeiro lugar. A forma atual de organizar a produção e distribuição daquilo que é produzido somente dá cabo daquelas necessidades como efeito colateral de um processo valorativo gerador de rentabilidade que se materializa na forma dinheiro, isto é, uma ordem produtiva que não tem como objetivo primeiro satisfazer aquelas necessidades dos seres humanos, mas sim gerar capital através do processo de exploração do trabalho humano e produção de mais valia resultando em valorização do valor, isto é, um aumento no montante do valor de troca resultando em lucro. Os seres humanos necessitam se sujeitar a tal exploração para poderem sobreviver e satisfazer suas necessidades materiais e imateriais que, no presente, são minuciosamente manipuladas pelo próprio sistema produtivo, por meio de mercadorias para manter a dinâmica de expansão da insaciável forma valor. A ânsia pelos elementos ganho e lucro faz com que o modo de produzir mercadorias avance em direção a todas as áreas da vida humana, transformando até o próprio ser humano numa mercadoria. 


\section{trabalhonecessário}

issn: 1808-799X

ano 9 - número 12 - 2011

Se Marx (1989, p. 04), no século XIX, observando e analisando os primórdios da segunda revolução industrial nos ensina: "A célula econômica da sociedade burguesa é a forma mercadoria, que reveste o produto do trabalho, ou a forma de valor assumida pela mercadoria", ele já percebe, naquele momento praticamente inicial, o poderio da forma valor neste processo de formação do capital. O trecho acima citado é do prefácio da primeira edição do Capital e ele praticamente revela o segredo de toda produção e produtores naquele sistema: todo objeto ou serviço, a fim de satisfazer necessidades humanas "provenham do estômago ou da fantasia" (Idem, p. 41), que atravessar os portões da fábrica, deixa de ser ele mesmo, transmuta-se em outro, é praticamente negado em sua materialidade, não deixando de sê-lo, "perceptível e impalpável" (Ibidem, p. 79), transforma-se em abstração, assume a forma de mercadoria, que tem em sua constituição precípua o valor. Tal abstração, cerne da ojeriza de alguns por Marx, é tão importante em sua teoria que ele the dedica um estudo minucioso. Todavia, talvez pelo valor de troca carregar características metafísicas, Marx (1989, p. 48) não ousa abandonar totalmente o valor de uso dos objetos, e a ele concede presença essencial: “...nenhuma coisa pode ser valor se não é objeto útil. Se não é útil, tampouco o será trabalho e, por isso, não cria nenhum valor." Contudo, ao analisar a mercadoria no sistema industrial de produção, ele é obrigado a se aproximar de algo próximo à metafísica, dado seu caráter além natural ${ }^{3}$, o conceito de "fetiche", desenvolvido por cientistas europeus que se ocupavam das práticas rituais existentes em grupos humanos ancestrais. Diz Marx (1989, p. 81), com extremo cuidado e sem perder a base física da relação: "Há uma relação física entre coisas físicas. Mas a forma mercadoria e a relação de valor entre os

\footnotetext{
${ }^{3}$ A professora Marilena Chauí (2003, p.183) a respeito da gênese da palavra metafísica nos ensina: "A palavra metafísica não foi empregada pelos gregos. Foi usada pela primeira vez por Andrônico de Rodes, por volta do ano 50 a. C., quando recolheu e classificou as obras de Aristóteles que, durante muitos séculos, haviam ficado dispersas e perdidas. Com essa sentença - tà meta tà physica -, o organizador dos textos aristotélicos indicava um conjunto de escritos que, em sua classificação, localizavam-se após os tratados sobre a física ou sobre a natureza, pois a palavra grega meta quer dizer 'depois de, após, acima de'.
} 


\section{trabalhonecessário}

issn: $1808-799 \mathrm{X}$

ano 9 - número 12 - 2011

produtos do trabalho, a qual caracteriza essa forma, nada tem a ver com a natureza física desses produtos nem com as relações dela decorrentes. Uma relação social definida, estabelecida entre os homens, assume a forma fantasmagórica de uma relação entre coisas. Para encontrar um símile, temos de recorrer à região nebulosa da crença."

Assim, analisando formas econômicas em uma verdadeira ontologia da forma mercadoria, Marx possibilita a outros pensadores, com base em suas análises mas vivendo um outro contexto, dar cabo de questões culturais, lingüísticas, filosóficas e psicanalíticas. O interesse de Marx ficou restrito ao campo da produção e da filosofia num contexto de incipiente industrialização e urbanização, mas naquele período o valor de troca ainda não poderia ser percebido em sua sobreposição sobre o valor de uso, ou seja, tal fato ainda não acontecia e os objetos eram adquiridos por suas qualidades intrínsecas. No entanto, num acirramento da forma mercadoria, isto é, com este modo de produção se alastrando por todas as partes do globo, a concorrência entre os produtores se recrudesce e o valor de troca, ajudado pela tecnologia, ultrapassa o valor de uso. Se no período de Marx o impacto cultural da nova maneira de produzir e reproduzir os bens necessários à vida dos seres humanos já foi grande, num ambiente de possível totalização da forma mercadoria, ele é a mais pura ontologia do ser social. Ou seja, a forma capitalista industrial de produção, ao totalizar a produção material e imaterial, alcança também as manifestações humanas englobadas pelo que hoje chamamos cultura. É em razão desse cenário que aparecem os trabalhos, por exemplo, dos pensadores que se convencionou denominar como "Escola de Frankfurt". Preocupados em explicar tal ontologia, esses intelectuais vão se debruçar sobre os desdobramentos do desenvolvimento tecnológico e cultural a partir da estrutura produtiva, mas sob o olhar crítico marxiano por eles contextualizado, isto é, levando em consideração o espraiamento e o aprofundamento da forma mercadoria sobre todos os âmbitos da vida dos homens e mulheres. 


\section{trabalhonecessário}

issn: 1808-799X

ano 9 - número 12 - 2011

Toda esta forma capitalista, que encapsula a produção, manipula e coloca limites objetivos aos seres humanos, alienando-os de si mesmos e dos seus próprios produtos por meio da quantificação do tempo, da separação entre tempo livre e de trabalho, da propriedade privada, da aceleração das atividades cotidianas, da alimentação imposta, da lógica do equivalente imposto a tudo na vida, dos limites salariais e das necessidades produzidas e impostas pela abstração socialmente denominada "mercado" - expressão e forma aparente da dialética da valorização do valor. Noutros termos, o aspecto objetivo, isto é, o ambiente, que possibilita a experiência formativa do ser humano é erigido pela forma produtiva, e não pela educação escolar, resultando numa educação do sujeito a partir de tal forma e não pela forma escolar, isto é, adaptando, delimitando e determinando as funções cognitivas e sensórias daquele. Pois como as manifestações do espírito humano rapidamente também são absorvidas pela forma social de produção, também se transformam em mercadorias. Ou seja, a cultura passa a obedecer à mesma lógica da produção do restante dos produtos necessários à sobrevivência dos seres humanos. Desta forma, a experiência possível da consciência é colapsada e reduzida ao esquematismo do valor de troca em seu movimento de reprodução ampliado e a manipulação e a destruição dos pouquíssimos lugares que ainda restava alguma autonomia se torna ainda mais fácil, rápida e eficiente, já que: "O caráter fetichista da mercadoria não é um fato da consciência, mas é dialético no sentido eminente de que ele produz consciência." (Adorno/Benjamin, 1994, p. 140; Adorno et ali., 1990, p. 111. In Maar, 2000, p. 08). Portanto, enclausurado pela forma produtiva do material, a mercadoria em seu processo de valorização do valor, o imaterial também se rende a tal forma, e a consciência é erigida no bojo desta última.

Ora, sob o presente contexto, será a educação escolar capaz de alterações no sistema produtivo nos dois sentidos postulados pelos seus demiurgos, isto é, em seu próprio movimento imanente: aquele que, pela educação formal, conseguirá destruir o exército de reserva e alcançar o pleno 


\section{trabalhonecessário}

issn: $1808-799 \mathrm{X}$

ano 9 - número 12 - 2011

emprego e, além disso, gerar no âmbito do próprio capitalismo industrial uma pletora de seres humanos pacíficos, solidários e tolerantes; e naquele transcendente ao próprio modo de produção capitalista, ou seja, a revolução por meio da educação?

Bem, diante de uma organização social que lança a materialidade, a partir da sua forma de produzi-la e o status que tal materialidade adquire, acima da vida dos próprios seres humanos, acredito ser absolutamente impossível empreender uma investigação sobre a educação formal, isto é, escolar - uma instituição eminentemente histórica -, sem abarcar o contexto econômico, social e cultural no qual ela está inserida, exatamente por seu caráter histórico, isto é, com vida presente numa específica organização produtiva. No entanto, a meu ver, tais elementos, que erigem o contexto em que a educação escolar, isto é, formal, se insere, não são apenas co-ajudantes dela, ou seja, estão em segundo plano, mas sim o contrário: a forma social atual de produzir e re-produzir a vida material determina a função social da escola indo além dela e determinando também o relacionamento dos seres humanos entre si e com aquela instituição educacional.

A composição orgânica do capital, ao admitir a fundamental necessidade do trabalho vivo, admite intrinsecamente um gasto de "nervos, músculos e cérebro" (Cf. Marx. 1989), mas não apresenta como um dado intrínseco e subentendido a exigência da escolarização. Pelo contrário, numa direção diametralmente oposta à necessidade de escolarização, a realidade originada pela relação social capitalista de produção reduz a possibilidade de experiências formativas dentro e fora do âmbito laboral e passa a engendrar atividades de pura repetição em que o trabalhador e o consumidor utilizam apenas uma memória muscular para executá-las; e naquelas em que há o uso menor dos músculos a tecnologia substituiu o cérebro e reduziu as tarefas a meros apertos de botões. Mesmo assim, a educação escolar, o mundo das puras idéias e da cultura, é colocada como ponto fundamental numa organização social em que é a materialidade o grande trunfo, o troféu absoluto. 


\section{trabalhonecessário}

issn: $1808-799 \mathrm{X}$

ano 9 - número 12 - 2011

Mais do que isso, o ponto fundamental reside no fato - já amplamente discutido, porém não enfocado como um agente anti-escolarização - de que esta materialidade, para ser produzida, está sob uma práxis econômica que é determinada pela rentabilidade, sendo este 0 elemento fundamental do processo criativo. Tal práxis se coloca sobre todos os âmbitos da relação humana, determinando-os conforme os princípios da valorização do valor, isto é, da rentabilidade, e delimitando as atividades, sensibilidade, impressões e cognição humanas. É, então, o ser social, oriundo, delimitado e determinado pela práxis material - não apenas a produtora, mas a consumidora também -, social e historicamente determinada que se eleva a construtor da consciência social, e não o contrário.

A rigor, com a forma capitalista a coagir produtores, produto e consumidores, há uma mudança no foco da produção em relação a formas produtivas historicamente anteriores: ela não mais objetiva as necessidades dos seres humanos, mas sim a expansão da própria produção num movimento tautológico que possui seu núcleo na valorização do valor de troca para gerar capital (Cf. Marx, 1989, pp. 41-78 e 165-175). Todo este sistema de produção e circulação, em seu movimento de expansão, tacitamente invade e passa a controlar a produção de tudo o que é necessário à vida dos seres humanos até em seus espaços mais íntimos: consciência, comportamento e tudo aquilo que concerne à experiência estética (sensibilidade, percepção, gosto), pois a forma social da produção material (valor), e o resultado desta (a mercadoria) colocam objetivamente os limites à experiência formativa humana, e esta acaba limitada a uma única possibilidade. Pois, como dito acima, a consciência social é fruto da vivência social do ser social e não o contrário Marx (Cf. 1991, p. 37). Nestes termos, mais atuais do que nunca, a materialidade é percebida como ela realmente é, ou seja, em seu status atual: preponderante a todo ser humano e, em sua forma capitalista de produção, atuando fortemente sobre aquele ser. Tal influência vai se acirrar ainda mais com o avanço tecnológico possibilitando o 


\section{trabalhonecessário}

issn: $1808-799 \mathrm{X}$

ano 9 - número 12 - 2011

advento do que Adorno e Horkheimer (2006, pp. 99-138) conceituaram como indústria cultural.

Desse modo, é a própria organização produtiva do mundo contemporâneo que minimiza a capacidade da educação escolar de interferir em tal organização, pois esta última lança seus tentáculos a todos os outros âmbitos da vida dos seres humanos, estruturando e organizando a vida social e cultural, e determinando a experiência formativa humana. Ora, se a experiência formativa do sujeito é balizada objetivamente pelos parâmetros do modo de produção, obstruindo a experimentação das contradições existentes na organização econômica social e colocando em seu lugar a falsidade da harmonia através da integração (econômica e cultural, pois os homens se irmanam a partir de suas mercadorias, tais como: veículos automotores e times de futebol), nosso problema é: pode a educação escolar, através de uma inserção circunscrita ao campo subjetivo, portanto mantendo as determinações objetivas (aquelas da forma da produção, produtora das relações sociais à revelia dos seres humanos) da experiência formativa, levar o sujeito a perceber aquela falsidade, as contradições existentes e alterar sua práxis social, assumindo sua posição antagônica à sociedade? Dito de outro modo, será a educação escolar capaz de ter poderes para desfazer tal sistema produtivo, originando a emancipação; ou, pelo menos, terá ela forças para inflar a inserção dos educandos em tal organização produtiva; ou ainda, minimamente civilizar os indivíduos, afastando a barbárie social que se materializa até nas próprias escolas? Em suma, mantendo-se as condições objetivas que, num passado recente, originaram Auschwitz, e hoje produzem a barbárie e mantém a heteronomia, pode uma ação circunscrita apenas ao âmbito das idéias alterar aquelas condições? Podem os sujeitos maciçamente se interessarem por tais idéias se há limitações objetivamente colocadas, isto é, a própria organização da forma produtiva calcada atualmente na ampliação do capital por meio da cultura em seu efeito retroativo da criação das necessidades? 


\section{trabalhonecessário}

issn: 1808-799X

ano 9 - número 12 - 2011

Se Maar (2003, p. 03), nitidamente baseado em Marx (1991), nos ensina que "consciência é 'ser consciente', reflexão da determinação do ser que é a existência, e não uma 'existência espiritual' contraposta dualisticamente à matéria 'inconsciente' ", podemos dizer, então, que isto significa que o ser humano atua socialmente hoje a partir de sua existência configurada nos termos de uma determinada forma de produção da vida material, isto é, longe de uma autonomia, mas totalmente coagido pela forma produtiva que organiza o mundo a sua volta. Todavia, se a autonomia é a possibilidade do indivíduo desenvolver suas capacidades a ponto de atuar em contradição com a organização social, como alcançar, por meio da educação escolar, tal estágio na configuração social ora apresentada, isto é, numa sociedade em que “...a organização social (...) continua sendo heterônoma, nenhuma pessoa pode viver conforme suas próprias determinações (...), a sociedade forma as pessoas mediante inúmeros canais e instâncias mediadoras de um modo tal que tudo absorvem..." (Adorno, 1995, p. 182) e:

A maneira pela qual uma jovem aceita e se desincumbe de um encontro obrigatório, a entonação no telefone e na mais familiar situação, a escolha das palavras na conversa, e até mesmo a vida interior organizada segundo os conceitos classificatórios da psicologia profunda vulgarizada, tudo isso atesta a tentativa de fazer de si mesmo um aparelho eficiente e que corresponda, mesmo nos mais profundos impulsos instintivos, ao modelo apresentado pela indústria cultural. (Adorno, 2006, p. 138)

Num complexo encadeamento produtivo com lógica própria e que se expandiu sobre todos os momentos da vida dos seres humanos e da natureza, fundando-os, determinando-os e reconfigurando-os, atuando tal qual um buraco negro e seu movimento entrópico, pode a educação apresentar os poderes de inserção e emancipação de tal lógica? Desse modo, isto é, admitindo e aceitando tal postulado, como é possível interpretar o "discurso" atual que coloca a educação (escolar) como entidade espiritual capaz de salvar o indivíduo e a nação das garras da pobreza, da barbárie e de tudo que há de mal 


\section{trabalhonecessário}

issn: 1808-799X

ano 9 - número 12 - 2011

no mundo (Cf. www.todospelaeducacao.org.br)? A educação pode levar à emancipação ou se tornou "cultura afirmativa" do sistema produtor de mercadorias, pois propagandeada enquanto elemento possibilitador da inserção dos indivíduos naquele sistema declina de modificá-lo, isto é, discutir com os indivíduos possibilidades de organização social para além dele (sistema produtor de mercadorias)? É possível, ainda, afirmar uma função ideal emancipatória à educação em face de uma realidade objetivamente reificada produtora de uma cultura afirmativa do vigente e da adaptação irrestrita dos indivíduos a tal vigente?

Se considerarmos a lógica própria e quase autônoma da forma produtiva atual e sua influência sobre todos os aspectos da vida humana, talvez, o melhor questionamento sobre o poder da educação escolar em relação a tal forma seja: é possível que a educação escolar - produzida no contexto da forma produtiva que engendra o capital, isto é, aquela que anseia por transformar a tudo e a todos em mercadoria rentável - seja capaz de se dissociar de tal contexto, escapando à dinâmica universalizadora do capital, e alterar a forma organizativa da produção e reprodução da sociedade, rompendo, ou pelo menos obstruindo, o movimento produtor de consciências do fetiche da mercadoria, ou seja, produzir consciências, "desfetichizando-as" sem dispor de meios materiais apenas ideais, e num ambiente absolutamente reificado? É possível atingir o esclarecimento numa sociedade de trevas, isto é, concretamente, objetivamente, não esclarecida? Pois se em primeiro plano e enquanto centro da sociedade está uma forma produtiva que engendra todo um ambiente propício a sua própria reprodução, todo o movimento social, e determina a relação dos seres humanos com o mundo, entre si e com o âmbito das idéias, será uma parte de tais idéias - aqui contemplada como educação escolar - capaz de alterações, mesmo que superficiais (aumentar as vagas de empregos ou solucionar os problemas de violência) nesta forma produtiva? É possível que tais idéias encontrem espaço para se efetivarem se a organização produtiva, enquanto determinante para as experiências formativas humanas, 


\section{trabalhonecessário}

issn: $1808-799 X$

ano 9 - número 12 - 2011

não permitir? Como a educação escolar em si mesma pode levar à emancipação se a realidade material, absolutamente refém da forma capitalista de produção, não permite a emancipação? Podem as idéias, originadas daquele tipo de educação, destruir a realidade reificada?

Forma valor, semiformação e emancipação por meio da educação: a experiência substitutiva à contradição social $\mathrm{e}$ a cultura afirmativa.

Neste momento, vivemos em uma realidade social em que o valor de troca, isto é, a forma que engloba toda a produção material da sociedade, é a categoria determinante de tal realidade. Essa forma organizativa da produção origina como seu correspondente subjetivo a forma social que Adorno (1986, pp. 388-411) conceituou como semiformação, impedindo que a experiência das contradições existentes no âmbito social e econômico seja realizada. Podemos dizer também que a forma adquirida pela produção, através do seu correspondente subjetivo, ou seja, a semiformação, impede a cultura escolar emancipatória de se efetivar, pois "quem compreende o que é poesia dificilmente encontrará um posto bem pago como autor de textos publicitários" (Adorno, 1986, p. 401). A socialização, desse modo, acontece, por seu lado objetivo, no âmbito erigido por meio da forma social da produção, isto é, aquela que transforma tudo em mercadoria, e, em seu lado subjetivo, nos parâmetros da semiformação. Esta realidade desconsidera qualquer motivo ideal fora dessas categorias. Assim, nossa hipótese é que a solução (educação escolar) dada ao problema (melhores condições de vida e das relações entre seres humanos e emancipação) é falsa, pois não considera que a forma de organização da produção se movimenta por meio de mecanismos de sua lógica própria (a exploração do trabalho; a produção de mais valia, valor, capital e sua expansão) como produtora também da realidade a sua volta parece apenas um problema de interação pessoal. 


\section{trabalhonecessário}

issn: 1808-799X

ano 9 - número 12 - 2011

Não que a educação seja sem importância, que o esclarecimento seja inócuo, ou que não haja uma relação tensa entre teoria e prática, mas o próprio processo de produção e reprodução material da vida e do mundo, ao engendrar um único molde - massivo - de possibilidade estética, uma experiência falsa, pois não humana e não autônoma, impede a assimilação de qualquer conteúdo fora daquele molde da semiformação. A produção econômica e social da realidade atual não permite brechas para se chegar a uma consciência emancipatória. Se toda determinação é negação, a consciência não se determina a si mesma, mas sim por meio do que não é ela mesma, isto é, realidade material. As idéias que encontram brechas na realidade material, produzida pela forma valor e reforçada pela indústria cultural, para se desenvolverem e formarem a consciência crítica, só podem se efetivar na prática. No entanto, o processo de formação dos indivíduos na sociedade produtora de mercadorias é determinado pelos limites objetivamente estabelecidos pelas relações de produção e pela indústria cultural, isto é, o movimento retroativo criador de necessidades e subsunção ao capital, expandindo-o. Este movimento é aquele gerador da valorização do valor transformado, ou duplicado, em cultura, isto é, produzindo mercadorias e, com isso, determinando capacidades do aparelho sensorial/perceptivo, comportamentos, formas e limites da cognição dos seres humanos: “(...) a indústria cultural como um todo (...) duplica na consciência dos homens o que existe." (Adorno, 1979, p. 175 APUD Maar, 2003, p. 02). A cultura e a realidade material não se desvinculam. Desse modo, a consciência não é produto dela mesma, isolada da materialidade constituinte do mundo, ela não é uma realização metafísica, é realizada em sua existência terrena, determinada por esta existência, limitada por ela. A semiformação é um produto objetivo da forma social que ora se impõe sobre o mundo, ela não é apenas consciência: são as condições objetivas da produção e reprodução material da vida humana que a originam. Sendo assim, a semiformação é erigida pela forma da produção 


\section{trabalhonecessário}

issn: $1808-799 \mathrm{X}$

ano 9 - número 12 - 2011

que dita os bens necessários à vida no capitalismo tardio, isto é, a maneira de produzir mercadorias. Portanto, ela é produto do capital e não da falta de educação escolar: "A semiformação seria a forma social da subjetividade determinada nos termos do capital." (Maar, 2003, p. 09)

Nestes termos, a emancipação não se dá por meio da educação, isto é, por meio de uma iluminação idealista ${ }^{4}$, mas sim, pela supressão do sistema que objetivamente a obstrui. A sujeição dos sujeitos não acontece apenas no âmbito das idéias, da consciência, ela é realizada objetivamente, é determinação produzida pela forma de produzir materialmente a vida dos seres humanos. Desta maneira, os limites da emancipação, isto é, do vir a ser da autonomia e da própria consciência emancipatória, são produzidos pelo modo de produção dos objetos necessários à vida material e atuam objetivamente, e não apenas idealmente. A consciência, a subjetividade e sua formação se encontram sendo produzidas fora do mundo escolar: "Cultura e formação precisam ser examinadas fora do âmbito estritamente cultural ou pedagógico definidos na sociedade, para serem investigadas no plano da própria produção social da sociedade em sua forma determinada" (Maar, 2003, p. 11). Esta "forma determinada" é o ponto. Ela determina a (semi) formação, ela reifica a formação semiformando o sujeito por mais escolarizado que ele seja, pois não há mais espaço para experiências não reificadas e que poderiam originar a emancipação, lembrando novamente a frase de Adorno: “...quem sabe realmente o que é poesia dificilmente encontrará um lugar como redator de publicidade" (Adorno, 1986, p. 115). Sendo assim: "A semiformação vai muito além de uma 'perturbação pedagógica' no interior de uma determinada situação social educacional. Refere-se a uma forma ordenada da sociedade contemporânea determinada conforme um certo modo de produção social dos homens e somente neste âmbito pode ser corretamente apreendida" (Maar,

\footnotetext{
${ }^{4}$ Tal qual um grupo não identificado, mas que se auto intitula "movimento mais feliz", e que conclama a população brasileira a assinar, via internet, uma petição para que uma emenda constitucional seja aprovada e, com ela, a felicidade para todos seja alcançada. Literalmente, há quem acredite em felicidade por decreto.
} 


\section{trabalhonecessário}

issn: $1808-799 \mathrm{X}$

ano 9 - número 12 - 2011

2003, p. 12). Há um movimento de relação entre a forma de produzir os que os seres humanos necessitam em sua vida - que determina as próprias necessidades - e a sociedade - a forma dos homens interagirem, pensarem, sentirem, se relacionarem, enfim, a cultura. Ou seja, a cultura e a materialidade estão em constante contato sendo ambas determinadas pela mesma forma social de produção. Em suma, a dinâmica que aciona o movimento gerador do capital atua na produção das necessidades materiais e imateriais da vida criando-as e satisfazendo-as retroativamente num único plano e não em locais distintos.

Desse modo, complementando nossa hipótese, podemos dizer que acreditamos não haver poder emancipatório na educação no âmbito da sociedade produtora de mercadorias do capitalismo tardio, já que ela é empreendida num campo devassado pela forma social que possui como único intuito a geração de capital. O mundo organizado até seus últimos rincões e em seus mínimos detalhes conforme o modo de produção capitalista não vai chegar ao fim por meio da educação escolar. A emancipação só pode ser conseguida para além de tal forma produtiva, em sua derrocada real que possibilitaria um espaço objetivo de práticas autônomas e experiências formativas e não semiformativas. Mesmo que o currículo se torne todo ele voltado à emancipação não são as idéias que trarão fim à reificação, porque o homem continuará reificado enquanto o ambiente real em que ele habita, isto é, em que ele se forma, for reificado. Noutros termos: se a consciência se produz a partir de experiências constituídas e limitadas por um ambiente real, ou pelo menos colocado como real e único possível, tal realidade impede uma experiência emancipatória. Sendo assim, apenas as idéias proferidas por uma educação escolar, mesmo que totalmente voltadas a um objetivo emancipador do homem sobre o capital, não surtirão efeito, pois, em tal organização social, as experiências, as sensações, os limites não serão oriundos dele (homem) ou de suas idéias, mas do ambiente social que o oprime, não permitindo a ele - 


\section{trabalhonecessário}

issn: 1808-799X

ano 9 - número 12 - 2011

agora não mais homem, mas produtor/consumidor/cidadão - a liberdade, a autonomia, a emancipação.

O representar, o pensar, o intercâmbio espiritual dos homens, aparecem aqui como emanação direta de seu comportamento material. O mesmo ocorre com a produção espiritual, tal como ocorre na linguagem da política, das leis, da moral, da religião, da metafísica, etc. de um povo. Os homens são os produtores de suas representações, de suas idéias, etc., mas os homens reais e ativos, tal como se acham condicionados por um determinado desenvolvimento de suas forças produtivas e pelo intercâmbio que a ele corresponde até chegar às suas formações mais amplas. A consciência jamais pode ser outra coisa do que o ser consciente, e o ser dos homens é o seu processo de vida real. (...) A moral, a religião, a metafísica e qualquer outra ideologia, assim como as formas de consciência que a elas correspondem, perdem toda a aparência de autonomia (...) Não é a consciência que determina a vida, mas a vida que determina a consciência. (Marx, 1991, pp 36-37; grifo nosso)

Para que a educação escolar surta efeitos positivos é necessário que haja um clima, um ambiente real, propício à própria escolarização dos indivíduos, isto é, é necessário que haja um estímulo social real à cultura escolarizada ou letrada, coisa que no atual momento inexiste. As experiências são objetivamente produzidas e controladas pela Indústria Cultural; sendo que, aquelas possibilitadoras de consciências voltadas à escolarização são substituídas pelas atividades impregnadas pela razão instrumental, isto é, aquelas que a sociedade produtora de mercadorias em sua ânsia de ganho e lucro considera propícias à venda de um produto, ou seja, uma mercadoria.

A própria idéia ora veiculada sobre a educação escolar como caminho para a resolução dos problemas do indivíduo - e, com isso, os do país -, incluindo-o ou emancipando-o, não passa de uma tentativa de induzir os que nela acreditarem ao que Adorno (2006, pp. 99-139) identificou quando de sua análise dos efeitos da Indústria Cultural sobre seus consumidores, e que Wolfgang Leo Maar (2000, p. 02-03) se refere e destaca, isto é, uma experiência substitutiva, já que por meio da crença naquela idéia como plenamente possível vive-se a experiência de uma organização social 


\section{trabalhonecessário}

issn: $1808-799 \mathrm{X}$

ano 9 - número 12 - 2011

harmoniosa, substituindo e mascarando a possibilidade de experimentar a verdade da sociedade, isto é, as contradições inerentes ao próprio sistema produtor de mercadorias e que impedem, mesmo aos indivíduos escolarizados, o acesso à emancipação. O "discurso" ideológico da educação como salvação apresenta soluções individuais para os problemas sociais e, dessa maneira, impede que os seres humanos apreendam a realidade social em sua forma contraditória e perversa. Tal posição ideológica acaba por servir à contra emancipação, em razão de direcionar a crítica, de forma fetichista, para o âmbito da cultura e preservar incólume a organização produtiva responsável pela produção da cultura e das consciências. A massificação da idéia de educação enquanto salvação apenas realiza a continuidade do vigente por meio de sua afirmação, já que a forma de produzir o mundo material e imaterial não necessita mudanças; o indivíduo é que deve se entregar ao discurso que permeia a tal "inclusão" neste vigente e mergulhar sem peias na educação, mas mantendo a estrutura produtiva em sua forma econômica e social sem nenhuma crítica.

Ora, em tal contexto discursivo e de idéias a educação assemelha-se ao que Marcuse (1997, pp. 89-135) conceituou como "cultura afirmativa", porque efetivamente há um reforço ideológico concernente à aceitação da organização do mundo produzido pelos seres humanos como ele se apresenta. Nesta, a educação cumpre o papel de inserir os seres humanos em suas respectivas funções sociais e econômicas - tornando-os cidadãos. Ou seja, o ser humano que anular-se e entregar-se aos poderes educativos da educação escolar certamente contemplará um resultado positivo em seu futuro (a tal inclusão) e seus esforços e sacrifícios terão valido a pena. Desse modo há, aparentemente, um completo desaparecimento das contradições objetivas do sistema e um reforço deste por meio da própria educação, pois a partir dela existe o caminho certeiro que levará o ser humano a uma boa vida inserindo-se na forma social/econômica produtora, distribuidora e comercializadora de mercadorias. A educação, portanto, aparece como um local privilegiado, absolutamente melhor 


\section{trabalhonecessário}

issn: $1808-799 \mathrm{X}$

ano 9 - número 12 - 2011

e infinitamente superior ao mundo material, não obstante, com o único intuito de levar a sua realização (material), pois se apresenta ao ser humano como uma possibilidade de inserção na forma material de produção e consumo. Aquele ser tem, com este discurso ideológico educativo, menos motivos para vislumbrar algum tipo de questionamento da forma atual de organização do mundo, pelo contrário, a possibilidade oferecida pela educação acaba por afirmar tal forma de organização e ajudar a apagar qualquer sombra ou vislumbre deste questionamento ou crítica. E, por outro lado, a tão esperada consciência, produzida a partir da educação e com viés revolucionário, não aconteceu - mesmo com sua massificação total, burguesa, diriam os ultraesquerdistas de plantão.

Desta forma consubstancia-se um contexto em que os apelativos discursos daqueles entusiastas da educação, sejam da direita ou da esquerda, políticos ou empresários, homens comuns ou intelectuais acadêmicos - mesmo que, muitos deles, cobertos de boas intenções - acabam por reforçar o que aparentemente, ou seja, de forma discursiva, desejam combater, isto é, a miséria, a pobreza, a violência, a falta de humanidade, em suma, a própria forma capitalista de produção e reprodução do mundo econômico e social. Porque, ao divulgarem tal discurso, postulando a inserção social por meio da educação escolar, e estimulando as massas a acreditarem nele, ajudam também a fazer com que essas mesmas massas acreditem na possibilidade de inserir-se na organização econômica e social capitalista, enquanto produtores e reais consumidores, como se nela houvesse lugar para todos. Com efeito, tal postulado apresenta como factível, a partir da educação, a desintegração da clássica apreensão de Marx (1989, Cf. pp. 502-517) dos problemas causados pelo avanço tecnológico sobre o emprego, ou seja, do exército de reserva - um elemento fundamental, segundo ele, para, em suma, manter baixo os salários dos trabalhadores empregados - e da complexa engenhosidade das formulações da composição dos salários para manter rentável a produção expostas por Marx (Cf. 1989, pp. 617-658); a convivência harmoniosa entre os 


\section{trabalhonecessário}

issn: $1808-799 \mathrm{X}$

ano 9 - número 12 - 2011

indivíduos; a inexistência de contradições na organização social ou entre indivíduos e tal organização e, enfim, a afirmação do que ora nos é apresentado como única forma de produzir e reproduzir a vida humana e tudo que emana dela, isto é, a forma capitalista industrial tardia de produção de mercadorias.

Pois, se levarmos em consideração o tão propalado objetivo da empregabilidade e de um número maior de vagas de trabalho através da educação escolar, logo perceberemos a grande falácia inerente a tal propaganda. O crescimento do número de vagas de emprego de qualquer setor da economia não cresce, e nunca crescerá enquanto for mantida a atual configuração do modo de produção capitalista, devido a uma maior escolarização de sua população, mas sim devido a um crescimento exponencial do mercado consumidor onde, para dar conta da demanda pelos produtos, apenas o avanço tecnológico não seja o suficiente e a valorização do valor, isto é, a rentabilidade seja factível. E mesmo assim ainda haverá a possibilidade das vagas criadas serem de trabalho precário, necessitando baixa escolarização e salários minúsculos. A própria condição de empregabilidade conseguida pelos indivíduos ao atravessarem cursos técnicos, universitários ou profissionalizantes, só realmente se efetiva após um longo período de experiência prática na função. A rigor, é fácil constatar que o mercado de trabalho valoriza especialmente a experiência efetiva na função a ser exercida e não apenas o conhecimento teórico sobre tal função.

Não obstante, ao percebermos e considerarmos tais fatos, também entendemos que os entusiastas da educação, munidos do "discurso" ideológico educacionista, mantém-na enquanto cultura afirmativa, numa configuração ainda mais precisa ao conceito de Marcuse (Cf. 1997, pp. 95-96), pois a exaltam como capaz de dissociar-se do mundo material e causar alterações neste mesmo mundo material, precisamente na forma de produzi-lo (forma produtiva). Este enaltecimento da educação vai além, mas se mantém afirmativo, no momento em que toma rumos aparentemente dissociados de fins 


\section{trabalhonecessário}

issn: 1808-799X

ano 9 - número 12 - 2011

utilitários, isto é, materiais. Neste momento, a educação, no discurso de seus demiurgos, assume cores correspondentes a um transporte capaz de levar os indivíduos nela envolvidos a locais muito acima do sujo e feio mundo material. Neste caso, educar-se seria refinar-se, alimentar o espírito, saldar a dívida com a alma, desenvolver um comportamento não violento, preocupar-se com seu semelhante, alcançar o belo e o justo. Em tal contexto, há o abandono de qualquer interesse em mudanças na organização social da produção material do mundo, já que a gratificação dos seres humanos emana de elementos espirituais, contidos na democratizada educação escolar, e não nos meios materiais que, a partir disso, podem ser organizados de qualquer maneira em sua produção e distribuição. Porém, mesmo tentando separar-se da materialidade, o enlace não é desfeito, porque a própria cultura afirmativa é produzida pelo contexto da produção material em sua forma capitalista industrial.

Tais observações erigem-se de uma abordagem do problema ideológico educacional a partir da totalidade da formação social. Pois há muito o "discurso" da educação como caminho da salvação humana foi assimilado por todas as instâncias sociais. Discordar de tal "discurso" quando ele se torna quase unânime até entre acadêmicos é uma tarefa bastante difícil e árdua. Porém, nossa percepção deve estar voltada para além do que a organização social nos apresenta como imediatamente real e verdadeiro, esta é a tarefa do pesquisador, crítico social ou cientista. Assim, percebemos (eu e aqueles que porventura lerem este artigo) que no momento em que a forma produtiva do capitalismo industrial tardo-desenvolvido, isto é, o sistema produtor de mercadorias, parece ter se tornado universal controlando e originando a tudo e a todos a partir de sua lógica própria, acreditar que a educação escolar possa mudar tal sistema ou ter algum nível de influência sobre ele é absolutamente questionável. A rigor, é a educação escolar que está a seus serviços, ou seja, sendo determinada por ele, e não o contrário, como o discurso simplista da 


\section{trabalhonecessário}

issn: 1808-799X

ano 9 - número 12 - 2011

educação enquanto salvação tenta defender. Pois muitos são aqueles que mesmo tendo estudado décadas a fio continuam numa situação precária economicamente; ainda há aqueles que, tendo passado pela mesma situação não desejam fazer crítica alguma à atual organização social e econômica do mundo, apenas desejam ansiosamente participar dela. Estes seres de boa fé é que justificam este estudo, ou seja, pela urgente necessidade de tentar barrar a falaciosa propaganda pró educação, pois ela tem servido apenas para que empresários desta área lucrem desmesuradamente. Portanto, a justificativa deste artigo se encerra na necessidade de desmistificar o discurso que atribui à educação escolar um poder revolucionário ou de inserção dos indivíduos no modo de produção capitalista industrial, como se ela fosse capaz de criar empregos, destruir a barbárie, civilizar e mudar o mundo.

Por tudo que foi escrito até agora, fica nítido que a cultura engendrada pelo capitalismo e seu corolário, isto é, a Indústria Cultural, produzem um contexto limitador e impositivo de experiências banais e extremamente pobres que educa as subjetividades, tornando-as totalmente moldáveis aos seus mais recentes e lucrativos produtos, sejam eles flores ou bombas. Dito de outro modo, são as próprias relações sociais criadas pelo sistema de valorização do valor, ampliado e tornado inexorável pela Indústria Cultural que educam os seres humanos e não a escola. Nesse processo há, a rigor, uma falsa harmonia reinante no âmbito da consciência comum. O tácito, ou explícito, espectro ideológico da modernidade inunda tal consciência com a falaciosa crença na marcha do progresso. Assim, as tensões entre os seres humanos e entre estes e o próprio âmbito social não existem e, junto com elas, inexiste também a realidade do embrutecimento da vida; em suma, as contradições desaparecem. Todas as relações e angústias humanas são passíveis de serem resolvidas, pois momentâneas. Sua resolução se dará por meio da chamada "inclusão". Esta solução demonstra a fé, a falsidade e a cegueira de alguns que se recusam a discutir a raiz dos problemas que originam a tão propalada necessidade de inclusão em razão da exclusão. Pois desejar apenas e tão 


\section{trabalhonecessário}

issn: $1808-799 \mathrm{X}$

ano 9 - número 12 - 2011

somente "incluir" aqueles que estão "excluídos", é admitir a existência de algo bom e perfeito do qual todo o ser humano deve fazer parte. Mais do que isso: é também afirmar a possibilidade de inclusão, e que, a partir dela, todos os problemas do incluído estarão resolvidos, já que acaba de adentrar a um mundo harmônico, estável e feliz. Contrapondo-nos a isso, emergimos com outra justificativa que colocamos para este estudo, isto é, a necessidade de percebermos a existência das contradições imanentes a esta organização social e dizermos não às soluções fictícias que dominam o espaço da consciência comum. Ou seja, verificarmos se o que está estabelecido enquanto crença, no que tange à educação e sua capacidade de inserção e mudança, corresponde realmente ao real ou continuará se situando apenas como uma crença estabelecida pela tradição advinda antes mesmo do sistema industrial, pois em determinados espaços, no período aludido, tal realidade se confirma, isto é, a educação foi realmente um elemento de acesso ao poder (Cf. Ringer, 2000, pp. 29-90).

Tais paradigmas, obtusos e equivocados, de análise educacional, advindos de outro momento da História humana, devem ser suprassumidos por aqueles que concentrem as análises na relação social e econômica em que está mergulhado o ser humano hoje. Esta relação é que verdadeiramente constitui o ambiente (semi) formativo em que está inserido o indivíduo atual e que tende a não permitir zonas minimamente autônomas para ninguém, por mais esclarecido que o indivíduo seja. Sendo assim, baseados em Marx, devese investigar a constituição do modo de produção capitalista industrial, sua lógica e sua dinâmica interna, com o objetivo de analisar se existe a possibilidade efetiva da educação escolar alterar tal lógica. Noutros termos, para aqueles estudiosos que desejam realmente entender o processo de crise educacional escolar atual cabe uma abordagem da totalidade da formação social e econômica e de seus desdobramentos em categorias, isto é, verificar o modo que o processo de produção de mercadorias se desenvolve, com 0 escopo de encontrar alguma necessidade fundamental deste em relação à 


\section{trabalhonecessário}

issn: $1808-799 \mathrm{X}$

ano 9 - número 12 - 2011

educação formal (escolar) e não apenas à sua própria lógica interna. Cabe explicitar, portanto, a necessidade de se utilizar uma metodologia que visa à análise teórica sob o enfoque marxista da produção e reprodução da realidade social determinando sua dinâmica e seus limites, ou seja, o método que aborda o processo de realização do capital, pois, em último plano e mesmo que não haja aqueles que assumam tal fato publicamente, toda a educação se remete a ele. Desta forma, é somente ao investigar a dinâmica da produção do capital que poderemos encontrar a resposta para nossa pergunta, isto é, se no processo de mediação interna do capital existe a necessidade de grandes massas educadas.

\section{BIBLIOGRAFIA}

ADORNO, Theodor W. Theodor W. Adorno: Sociologia. Coleção grandes cientistas sociais COHN, Gabriel (org.). São Paulo: Ática, 1986.

- Teoria da semicultura. In: Educação \& Sociedade: revista quadrimestral de ciência da educação, ano XVII, n. 56, Campinas: Editora Papirus, dez., 1996.

. O Fetichismo na música e a regressão da audição. In:

Os pensadores. São Paulo: Nova Cultural, 1999. . Indústria cultural e sociedade. São Paulo: Paz e Terra, 2002.

- Resumo sobre indústria cultural. Disponível em: http://antivalor2.vilabol.uol.com.br/textos/frankfurt/adorno/adorno 26html.

Acesso em 15 dez. 2007.

Educação para quê? Disponível em: http://adorno.planetaclix.pt/tadorno15.htm. Acesso em 04/03/2004.

Televisão e formação. Disponível em: http://adorno.planetaclix.pt/tadorno11.htm. Acesso em 04/03/2004.

Educação após Auschwitz. Disponível em: http://adorno.planetaclix.pt/tadorno10.htm. Acesso em 04/03/2004. 


\section{trabalhonecessário}

issn: 1808-799X

ano 9 - número 12 - 2011

Educação contra a barbárie. Disponível em:

http://adorno.planetaclix.pt/tadorno2.htm. Acesso em: 04/03/2004.

. Sobre sujeito e objeto. Disponível em:

http://adorno.planetaclix.pt/tadorno2.htm. Acesso em: 26/02/2004.

ADORNO, Theodor W., HORKHEIMER, Max. O Conceito de iluminismo. In: Os pensadores. São Paulo: Nova Cultural, 1999.

A Indústria Cultural. In:

Dialética do Esclarecimento. Rio de Janeiro: Jorge Zahar, 2006.

CHAUÍ, Marilena. Convite à filosofia. São Paulo: Ática, 2003.

HORKHEIMER, Max; Adorno, Theodor W. Temas básicos de sociologia. São Paulo: Cultrix, 1973.

MAAR, Wolfgang L. Adorno, semiformação e educação. Revista eletrônica Educação \& Sociedade. vol. 24, n.83, Campinas, Agosto 2003.

MAAR, Wolfgang L. Educação crítica, formação cultural e emancipação política na Escola de Frankfurt. In: PUCCI, Bruno (org.). Teoria crítica e educação: a questão da formação cultural na Escola de Frankfurt. Rio de Janeiro: Vozes; São Paulo: EDUFSCAR, 2007.

- À guisa de introdução: Adorno e a experiência formativa. In: Adorno, Theodor W. Educação e Emancipação. Rio de Janeiro, Paz e Terra, 1995.

MAAR, Wolfgang L. A produção da "sociedade" pela Indústria Cultural. Revista Olhar. Ano 2. n. 3. Junho 2000.

MAIA, Ari F. Arte, Técnica e indústria Cultural. Interface - Comunicação, Saúde e Educação. Vol. 4. n. 6. Botucatu. Fev. 2000.

MARCUSE, Herbert. Ideologia da sociedade industrial. Rio de Janeiro: Zahar editores, 1967.

- Sobre o caráter afirmativo da cultura. In: Cultura e sociedade vol. I. São Paulo: Paz e Terra, 1997.

. Industrialização e capitalismo na obra de Max Weber.

In: Cultura e sociedade (vol. 2). São Paulo: Paz e Terra, 1998. 


\section{trabalhonecessário}

issn: 1808-799X

ano 9 - número 12 - 2011

Algumas Implicações sociais da tecnologia moderna.

In: Tecnologia guerra e fascismo. São Paulo: Unesp, 1999.

. Liberdade e agressão na sociedade tecnológica.

Disponível

em:

http://antivalor.vilabol.uol.com.br/textos/frankfurt/marcuse/tx marcuse 004.htm.

Acesso em: 10 mar. 2008.

MARX, Karl. Mercadoria e dinheiro. In: 0 capital. Rio de Janeiro: Bertrand Brasil, 1989. v. 1.

RINGER, Fritz K. O Declínio dos mandarins alemães. São Paulo: Edusp, 2000. 